\title{
Regulasi Diri Pengguna Media Sosial dengan Motivasi Belajar Siswa
}

\author{
Sitti Mikarna Kaimuddin ${ }^{1}$, Barlian $^{2}$, Nuningsih ${ }^{3}$ \\ Jurusan Psikologi \\ Fakultas Keguruan dan Ilmu Pendidikan, Universitas Halu Oleo \\ smikarnak@uho.ac.id', barlian@uho.ac.id², nuningsih1997@gmail.com³
}

\begin{abstract}
Abstrak : Kehadiran media sosial di kalangan remaja membuat mereka mengabaikan tugasnya sebagai pelajar karena sering menghabiskan waktu mengakses media sosial yang berdampak pada motivasi belajarnya. Siswa yang memiliki motivasi belajar yang baik diharapkan mampu mengatur perilakunya dalam menggunakan media sosial yang ditandai dengan adanya pengaturan diri dalam menggunakan media sosial. Penelitian ini bertujuan untuk mengetahui apakah terdapat hubungan antara regulasi diri pengguna media sosial dengan motivasi belajar pada siswa di SMAN 1 Kendari. Subjek dalam penelitian ini berjumlah 65 orang siswa kelas XI di SMAN 1 Kendari yang menggunakan media sosial lebih dari 8 jam dengan teknik pengambilan sampel yang digunakan adalah nonprobability sampling jenis purposive sampling. Instrumen penelitian ini menggunakan skala regulasi diri pengguna media sosial dan motivasi belajar. Jenis penelitian ini yaitu kuantitatif dengan desain penelitian korelasional. Data penelitian dianalisis menggunakan melalui uji korelasi. Hasil penelitian menunjukkan nilai signifikansi sebesar 0,000. Nilai tersebut lebih kecil dari 0,05 artinya terdapat hubungan yang signifikan antara regulasi diri pengguna media sosial dengan motivasi belajar siswa SMAN 1 Kendari. Lebih lanjut peneliti menemukan hubungan positif antara regulasi diri pengguna media sosial dan motivasi belajar dengan nilai koefisien korelasi sebesar 0.608. Artinya, semakin tinggi regulasi diri pengguna media sosial, maka semakin tinggi pula motivasi belajar siswa.
\end{abstract}

Kata Kunci : regulasi diri; media sosial; motivasi belajar.

Abstract: The presence of social media among teenagers makes them neglect their duties as students because they often spend time accessing social media which has an impact on their learning motivation. Students who have good learning motivation are expected to be able to regulate their behavior in using social media which is marked by self-regulation in using social media. This research aimed to determine whether there is a relationship between selfregulation of social media users and student motivation at SMAN 1 Kendari. Subjects in this research were 65 students of class XI at SMAN 1 Kendari who used social media for more than 8 hours with the sampling technique used was purposive sampling type non probability sampling. This research instrument uses a scale of self-regulation of social media users and learning motivation. The type of research is quantitative with a correlational research design. The research data were analyzed using the correlation test. The results showed a significance value of 0.000. This value is less than 0.05, which means that there is a significant relationship between self-regulation of social media users and student motivation at SMAN 1 Kendari. Furthermore, the researcher found a positive relationship between selfregulation of social media users and learning motivation with a correlation coefficient of 0.608. This means that the higher the self-regulation of social media users, the higher the student's motivation to learn.

Keywords: self-regulation; social media; motivation to learn. 


\section{Pendahuluan}

Pada era globalisasi saat ini, internet merupakan sesuatu yang sudah tidak asing lagi di kalangan masyarakat khususnya di Indonesia. Melalui internet semua hal bisa menjadi serba online dan dapat terhubung satu sama lain walaupun dengan jarak yang sangat jauh. Internet memberikan kemudahan bagi setiap individu dalam berkomunikasi atau berinteraksi satu sama lain melalui berbagai macam media sosial. Melalui media sosial setiap orang dapat melakukan berbagai aktivitas seperti mencari teman baru, mencari informasi, membantu komunikasi jarak jauh, ataupun saling bertukar gambar. Media sosial tersebut seperti Instagram, Facebook, WhatsApp, Twitter, dan lain-lain.

Kehadiran media sosial di kalangan remaja, membuat ruang privat seseorang melebur dengan ruang publik. Terjadi pergeseran budaya di kalangan remaja, para remaja tidak segan-segan mengupload segala kegiatan pribadinya untuk disampaikan kepada teman-temannya melalui akun media sosial dalam membentuk identitas diri mereka (Ayun, 2015). Sehingga dapat dikatakan bahwa remaja senang melakukan kegiatan tertentu yang dapat mereka upload di akun media sosial masing-masing untuk sekedar memperlihatkan kepada ruang publik.

Media sosial saat ini telah menjadi fenomena yang hangat di kalangan masyarakat khususnya bagi para remaja, menggunakan media sosial menjadi suatu kewajiban setiap harinya bahkan setiap menit. Dimana penggunaan media sosial di kalangan remaja saat ini merupakan sesuatu yang tidak dapat dihindari lagi dan telah menjadi suatu fenomena menarik. Adapun fenomena remaja menggunakan media sosial dalam membentuk identitas yaitu yang pertama, untuk menunjukkan identitas diri yang berbeda-beda. Kedua, para remaja menggunakan media sosial dikarenakan mereka ingin menjalin komunikasi dengan teman-teman mereka, sehingga mereka memutuskan untuk memiliki akun media sosial lebih dari satu. Ketiga, nilai individu yang ditampilkan dalam media sosial, para remaja mencoba membuat sebuah citra positif tentang diri mereka, menampilkan identitas mereka yang smart, terlihat bahagia, dan suka menampilkan kegiatan atau hobi yang mereka sukai. Keempat, para remaja cukup terbuka di media sosial dalam menunjukkan identitas mereka, hal ini ditunjukkan dengan keterbukaan diri mereka melalui keinginan mereka untuk eksis dan meng-upload kegiatan yang sedang mereka lakukan (baik melalui foto ataupun status) dan mengungkapkan permasalahan pribadi di media sosial dalam bentuk tersirat.

Menurut Santrock (2007) ada beberapa hal yang dapat mempengaruhi remaja, salah satunya adalah media sosial. Dimana media sosial banyak memberikan berbagai kemudahan yang berdampak positif bagi setiap individu yang menggunakannya, misalnya sebagai media komunikasi yang baik dan mudah bagi setiap orang, sebagai sarana promosi, serta dapat pula sebagai sarana hiburan (menonton video atau bergabung dengan komunitas tertentu). Namun selain dampak positif, media sosial juga dapat memberikan dampak negatif bagi penggunanya khususnya bagi para remaja yang sedang bersekolah yaitu dapat mengganggu kegiatan belajar mereka.

Media sosial dapat berdampak pada beberapa hal diantaranya pola tidur (Hepilita \& Gantas, 2018), tingkat kepekaan sosial (Aprinta \& Dwi, 2017), kualitas tidur (Jarmi, 2017), prestasi belajar (Khoiriyyah, Thohari, \& Jazari, 2018), serta dapat pula mempengaruhi motivasi belajar (Rismana, Normelani, \& Adyatma, 2016). Namun dalam penelitian ini berfokus pada motivasi belajar, yaitu untuk melihat motivasi belajar siswa di sekolah yang menggunakan media sosial. Hal ini sejalan dengan penelitian Putri, Nurwati, dan Santoso (2016) yang menyatakan bahwa dampak negatif bagi remaja pengguna media sosial yang dapat mengganggu aktivitas belajar mereka. Terganggunya aktivitas belajar siswa dapat mempengaruhi motivasi belajar. 
Menurut Uno (2017) hakikat motivasi belajar adalah dorongan internal dan eksternal pada siswa-siswa yang sedang belajar untuk mengadakan perubahan tingkah laku untuk mencapai harapan atau cita-cita masa depan. Menurut Hamdu dan Agustina (2011), motivasi belajar adalah suatu usaha seseorang untuk menggerakkan, mengarahkan dan menjaga tingkah lakunya agar terdorong untuk melakukan sesuatu guna mendapat hasil yang baik dalam belajar. Sedangkan menurut Maryani (2016), motivasi belajar adalah keseluruhan daya penggerak di dalam diri siswa yang menimbulkan kegiatan belajar, menjamin kelangsungan kegiatan belajar demi mencapai suatu tujuan.

Dari pengertian tersebut dapat disimpulkan pengertian motivasi belajar yaitu keseluruhan daya penggerak atau dorongan dari dalam diri siswa yang memberi arah untuk melakukan kegiatan belajar guna mencapai tujuan atau cita-cita masa depan.

Berdasarkan hasil wawancara dengan beberapa siswa di SMAN 1 Kendari, diperoleh gambaran bahwa mereka adalah pengguna aktif media sosial. Mereka menggunakan media sosial di rumah maupun di sekolah, walaupun sedang belajar. Sehingga hal tersebut membuat mereka sering kali mengabaikan kegiatan belajar dan tidak menyelesaikan tugas dengan baik. Mereka juga sering tidur di atas jam 12 malam karena bermain media sosial, sehingga menyebabkan mereka terlambat bangun pagi untuk ke sekolah.

Adapun data yang peneliti peroleh mengenai durasi atau waktu yang siswa habiskan untuk menggunakan media sosial tentunya berbeda-beda. Peneliti membagi durasi atau waktu penggunaan media sosial siswa dari hasil data yang diperoleh di lapangan menjadi 5 kelompok. Kelompok pertama adalah pengguna media sosial 1-2 jam yang berjumlah 32 siswa. Kedua, kelompok pengguna media sosial 3-4 jam yang berjumlah 68 siswa. Ketiga, kelompok pengguna media sosial 5-6 jam yang berjumlah 84 siswa. Keempat, kelompok pengguna media sosial 7-8 jam yang berjumlah 121. Kelima, kelompok pengguna media sosial 8 jam ke atas yang berjumlah 122. Data tersebut diperoleh dari jumlah 427 siswa kelas XI di SMAN 1 Kendari. Pembagian waktu tersebut berdasarkan dari penelitian yang dilakukan oleh Wang, Chen, Wei, dan Liang (2011) yang menyatakan bahwa banyak siswa yang menghabiskan waktu di atas 8 jam untuk mengakses media sosial sehingga hal tersebut menyita waktu belajar dan mengganggu aktivitas belajar mereka.

Dari hasil wawancara dan data survei di atas, menunjukkan adanya dampak negatif yang disebabkan oleh penggunaan media sosial yang mengganggu aktivitas belajar serta banyak siswa yang menggunakan media sosial lebih dari 8 jam yang banyak menyita waktu. Sehingga diperlukan suatu hal yang dapat mengontrol perilaku siswa dalam menggunakan media sosial.

Menurut Bandura (1989) kemampuan regulasi diri didasari dengan adanya standar yang ditetapkan oleh individu itu sendiri. Tanpa standar yang digunakan untuk mengukur kinerja mereka, orang hanya memiliki sedikit dasar untuk mengukur kemampuan mereka. Standar yang menantang meminta keterlibatan berkelanjutan dalam tugas-tugas yang diperlukan untuk membangun kompetensi yang menumbuhkan minat. Menurut Manab (2016), regulasi diri merupakan proses individu untuk mengatur dan memperbaiki diri serta mempunyai tujuan atau target, dan ketika selesai pada pencapaian, maka ada proses mengevaluasi pencapaian tersebut, ketika proses maksimal dapat tercapai individu biasanya merasakan kepuasan dalam dirinya. Sedangkan menurut Ormrod (Nurillah \& Chusairi, 2018), regulasi diri merupakan salah satu kunci keberhasilan dalam mencapai tujuan, seseorang yang memiliki kemampuan regulasi diri yang baik akan 
mampu untuk memunculkan motivasi dirinya untuk mencapai tujuan yang diinginkan. Dari definisi tersebut maka dapat disimpulkan bahwa seseorang yang melakukan regulasi diri memiliki standar yang ingin dicapai di masa depan. Ketika seseorang mampu mengatur perilaku mana yang sesuai dan tidak sesuai maka orang tersebut telah terlibat dalam regulasi diri. Individu yang melakukan regulasi diri tentunya akan memberikan manfaat untuk lebih terarah dalam mencapai tujuan yang ingin dicapai di masa depan. Jadi, regulasi diri pengguna media sosial adalah siswa yang mampu mengatur diri dalam menggunakan media sosial sehari-hari pada saat belajar baik di sekolah maupun di rumah dengan cara mengawasi atau mengontrol perilakunya sendiri untuk mencapai tujuan yang ingin dicapai.

Penelitian yang dilakukan oleh Mustofa (2014) mengenai "Hubungan Konsep Diri Dengan Motivasi Belajar Siswa Kelas XII IPS MAN 1 Kota Blitar". Hasil penelitian menunjukkan adanya hubungan positif antara konsep diri dengan motivasi belajar siswa. Semakin tinggi konsep diri maka semakin tinggi pula motivasi belajar siswa.

Penelitian yang dilakukan oleh Febritama dan Sanjaya (2018) mengenai "Hubungan antara Regulasi Diri dengan Perilaku Prokrastinasi Akademik pada Mahasiswa" menunjukkan bahwa terdapat hubungan negatif adanya hubungan negatif antara regulasi diri dan perilaku prokrastinasi akademik pada mahasiswa Universitas X Surabaya.

Penelitian yang dilakukan oleh Rismana, Normelani, dan Adyatma pada tahun 2016 mengenai "Pengaruh jejaring sosial terhadap motivasi belajar siswa-siswi sekolah menengah pertama (SMP) di Kecamatan Banjarmasin Barat". Hasil penelitian menunjukkan bahwa secara keseluruhan terdapat pengaruh yang signifikan antara penggunaan jejaring sosial terhadap motivasi belajar siswa-siswi di Kecamatan Banjarmasin Barat Tahun Pelajaran 2015/2016.
Perbedaan antara penelitian sebelumnya dengan penelitian ini yaitu memiliki salah satu variabel yang dikaitkan berbeda, lokasi penelitian yang dilakukan berbeda, serta kriteria subjek yang diteliti juga berbeda. Persamaannya adalah samasama memiliki salah satu variabel yang sama. Sehingga hal itu memberikan makna, bahwa perlu dilakukan penelitian untuk menemukan adanya hubungan antara regulasi diri pengguna media sosial dengan motivasi belajar siswa SMAN 1 Kendari.

Berdasarkan uraian di atas, maka peneliti tertarik untuk melakukan penelitian yang berjudul hubungan antara regulasi diri pengguna media sosial dengan motivasi belajar siswa SMAN 1 Kendari.

Rumusan masalah dalam penelitian ini yaitu apakah terdapat hubungan yang signifikan antara regulasi diri pengguna media sosial dengan motivasi belajar siswa di SMAN 1 Kendari.

Berdasarkan rumusan masalah yang telah diuraikan, maka tujuan yang ingin dicapai dari penelitian ini adalah untuk mengetahui apakah terdapat hubungan antara regulasi diri pengguna media sosial dengan motivasi belajar siswa di SMAN 1 Kendari.

Hipotesis yang diajukan dalam penelitian ini adalah terdapat hubungan yang signifikan antara regulasi diri pengguna media sosial dengan motivasi belajar siswa di SMAN 1 Kendari.

\section{Metode Penelitian}

Penelitian ini merupakan penelitian kuantitatif menggunakan desain korelasional dengan mempelajari keeratan hubungan antara variabel bebas dan variabel terikat. Variabel bebas dalam penelitian ini adalah regulasi diri pengguna media sosial sedangkan variabel terikat adalah motivasi belajar. Populasi dalam penelitian ini adalah seluruh siswa kelas XI di SMAN 1 Kendari yang menggunakan media sosial lebih dari 8 jam berjumlah 122 siswa. Teknik pengambilan sampel yang digunakan adalah nonprobability sampling jenis purposive sampling. 
Purposive sampling adalah teknik penentuan sampel dengan pertimbangan atau kriteria-kriteria tertentu. Sampel dalam penelitian ini terdiri dari 65 siswa kelas XI SMAN 1 Kendari. Adapun kriteria dari pengambilan sampel dalam penelitian ini adalah (1) Siswa yang menggunakan media sosial, (2) Siswa yang menggunakan media sosial di rumah maupun di sekolah, (3) Siswa yang menggunakan media sosial saat belajar di rumah atau di sekolah, (4) Siswa yang menggunakan media sosial lebih dari 8 jam dalam sehari.

Metode pengumpulan data digunakan menggunakan 2 skala, yaitu skala regulasi diri pengguna media sosial dan skala motivasi belajar. Skala regulasi diri pengguna media sosial terdiri dari pernyataan-pernyataan yang bersifat favorabel dan unfavorable yang berisi 64 aitem dan skala motivasi belajar terdiri dari 48 aitem.

Uji hipotesis dilakukan menggunakan uji korelasi dengan teknik Product Moment Pearson yang diolah menggunakan program SPSS (Statistical Product and Service Solution) 21.0 for Windows dengan taraf signifikansi 0.05 atau 5\%. Untuk mengetahui apakah data terdistribusi secara normal, data diolah menggunakan teknik Kolmogrov Smirnov dan apakah jenis data tersebut berhubungan secara linear atau tidak maka data diolah dengan menggunakan Test for Linearity.

\section{Hasil Penelitian dan Pembahasan}

Uji Normalitas data dengan menggunakan teknik One-Sample Kolmogrov Smirnov pada Statistical Product and Service Solutions 21.0 menunjukkan nilai signifikansi variabel regulasi diri sebesar 0,811 dan variabel motivasi belajar sebesar 0,766. Nilai signifikansi tersebut lebih besar dari 0,05, ini menunjukkan bahwa data variabel regulasi diri pengguna media sosial dan variabel motivasi belajar terdistribusi secara normal.
Tabel 1. Uji Normalitas

\begin{tabular}{lll}
\hline \multicolumn{1}{c}{$\mathrm{V}$} & $\begin{array}{l}\text { Kolmog } \\
\text { orov- } \\
\text { Smirnov }\end{array}$ & Signifikansi \\
\hline $\begin{array}{l}\text { Regulasi diri } \\
\text { pengguna media }\end{array}$ & 0.638 & 0.811 \\
$\begin{array}{l}\text { sosial } \\
\text { Motivasi belajar }\end{array}$ & 0.666 & 0.766 \\
\hline
\end{tabular}

Uji linearitas dimaksudkan untuk mengetahui apakah variabel yang akan digunakan mempunyai hubungan yang linear ataukah tidak dengan variabel bebasnya. Uji Linearitas data dengan menggunakan Test for Linearity pada program Statistical Product and Service Solutions versi 21.0 menunjukkan nilai signifikansi deviation from linearity sebesar 0,516. Nilai ini lebih besar dari 0,05 , ini menunjukkan bahwa data variabel regulasi diri pengguna media sosial dan variabel motivasi belajar mempunyai hubungan yang linear.

Tabel 2. Uji Linearitas

\begin{tabular}{ll}
\hline \multicolumn{1}{c}{$\mathrm{V}$} & $\begin{array}{l}\text { Signifikansi } \\
\text { Deviation } \\
\text { from } \\
\text { linearity }\end{array}$ \\
\hline $\begin{array}{l}\text { Regulasi diri } \\
\text { pengguna media } \\
\text { sosial } \\
\text { Motivasi belajar }\end{array}$ & 0.516 \\
\hline
\end{tabular}

Uji hipotesis dilakukan dengan menggunakan analisis korelasi Pearson Product Moment dengan menggunakan bantuan program Statistical Product and Service Solutions versi 21.0 for windows. Hasil data menunjukkan nilai signifikansi 0.000 , nilai ini lebih kecil dari 0,05 , sehingga dapat dikatakan bahwa terdapat hubungan yang signifikan antara regulasi diri pengguna media sosial dengan motivasi belajar siswa SMAN 1 Kendari. Nilai korelasi pearson menunjukkan angka 0,608, yang artinya terdapat korelasi positif. 
Tabel 3. Uji Korelasi

\begin{tabular}{ccc}
\hline Variabel & $\begin{array}{c}\text { Korelasi } \\
\text { pearson }\end{array}$ & $\begin{array}{c}\text { Sig. } \\
\text { Deviation } \\
\text { From } \\
\text { Linearity }\end{array}$ \\
\hline $\begin{array}{c}\text { Regulasi diri } \\
\text { pengguna media } \\
\text { sosial } \\
\text { X }\end{array}$ & 0,608 & 0.000 \\
Motivasi belajar & & \\
\hline
\end{tabular}

Berdasarkan hasil penelitian, maka dapat disimpulkan bahwa hipotesis dalam penelitian ini diterima, terdapat hubungan antara regualasi diri pengguna media sosial dengan motivasi belajar siswa SMAN 1 Kendari. Dimana media sosial saat ini merupakan suatu rutinitas bagi siswa di setiap harinya untuk selalu aktif menggunakannya. Para remaja cukup terbuka di media sosial dalam menunjukkan identitas diri mereka. Hal ini ditunjukkan dengan keterbukaan diri mereka melalui akun media sosial yang memperlihatkan kegiatan mereka sehari-hari. Ketika siswa terlalu aktif dalam menggunakan media sosial, maka hal tersebut dapat mempengaruhi motivasi belajar. Hal ini didukung dengan penelitian yang dilakukan oleh Rismana, Normelani, dan Adyatma (2016) menunjukkan bahwa secara keseluruhan terdapat pengaruh yang signifikan antara penggunaan jejaring sosial terhadap motivasi belajar siswa-siswi di Kecamatan Banjarmasin Barat Tahun Pelajaran 2015/2016.

Menurut Uno (2017) hakikat motivasi belajar adalah dorongan internal dan eksternal pada siswa-siswa yang sedang belajar untuk mengadakan perubahan tingkah laku untuk mencapai harapan atau cita-cita masa depan. Jadi, motivasi belajar merupakan suatu hal yang sangat penting bagi siswa dalam mengejar cita-cita atau harapan yang ingin dicapai di masa depan sebagai bentuk dorongan baik internal maupun secara eksternal.

Sesuai dengan fenomena di lapangan siswa SMAN 1 Kendari menunjukkan adanya dampak negatif yang disebabkan oleh penggunaan media sosial yang mengganggu aktivitas belajar serta banyak siswa yang menggunakan media sosial lebih dari 8 jam yang banyak menyita waktu. Penelitian yang dilakukan oleh Wang, Chen, Wei, dan Liang (2011) banyak siswa yang menghabiskan waktu di atas 8 jam untuk mengakses media sosial, hal tersebut menyita waktu belajar dan mengganggu aktivitas belajar mereka, sehingga diperlukan suatu yang hal yang dapat mengontrol perilaku siswa dalam menggunakan media sosial.

Menurut penelitian yang dilakukan oleh Friskilia dan Winata (2018) tentang regulasi diri (pengaturan diri) sebagai determinan hasil belajar siswa sekolah menengah kejuruan, menyatakan bahwa regulasi diri memiliki pengaruh yang positif dan signifikan terhadap hasil belajar siswa. Hal ini menunjukkan bahwa jika kemampuan regulasi diri siswa meningkat maka hasil belajar siswa akan meningkat, begitupun sebaliknya. Selain itu, penelitian yang dilakukan oleh Sifa dan Sawitri (2018) tentang hubungan regulasi diri dengan adiksi media sosial pada siswa SMK Jayawisata Semarang, menyatakan bahwa terdapat korelasi negatif yang signifikan antara regulasi diri dan adiksi media sosial pada siswa SMK Jayawisata Semarang. Artinya, semakin tinggi regulasi diri maka semakin rendah adiksi media sosial pada siswa SMK Jayawisata Semarang. Berdasarkan penelitian tersebut maka regulasi diri dapat digunakan sebagai pengontrol siswa dalam menggunakan media sosial.

Menurut Bandura (1989) kemampuan regulasi diri didasari dengan adanya standar yang ditetapkan oleh individu itu sendiri. Tanpa standar yang digunakan untuk mengukur kinerja mereka, orang hanya memiliki sedikit dasar untuk mengukur kemampuan mereka. Standar yang menantang meminta keterlibatan berkelanjutan dalam tugas-tugas yang diperlukan untuk membangun kompetensi yang menumbuhkan minat. Selanjutnya 
Bandura (Boeree, 2013), menyatakan bahwa regulasi diri (kemampuan mengontrol diri sendiri) adalah salah satu dari sekian penggerak utama kepribadian manusia yang terjadi melalui tiga proses yaitu pengamatan diri, penilaian, dan respon diri.

Menurut Zimmerman (1990), regulasi diri mengacu pada tindakan dan proses yang diarahkan pada perolehan informasi atau keterampilan yang melibatkan persepsi agensi, tujuan, dan instrumentalitas oleh peserta didik. Zimmerman (1990) meyakini bahwa semua peserta didik menggunakan proses pengaturan sampai tingkat tertentu, tetapi peserta didik yang diatur sendiri dibedakan oleh dua hal. Pertama, kesadaran mereka tentang hubungan strategis antara proses pengaturan atau tanggapan dan hasil pembelajaran. Kedua, penggunaan strategi ini untuk mencapai tujuan akademik mereka.

Dari definisi tersebut maka dapat disimpulkan bahwa seseorang yang melakukan regulasi diri memiliki standar yang ingin dicapai di masa depan. Ketika seseorang mampu mengatur perilaku mana yang sesuai dan tidak sesuai maka orang tersebut telah terlibat dalam regulasi diri. Individu yang melakukan regulasi diri tentunya akan memberikan manfaat untuk lebih terarah dalam mencapai tujuan yang ingin dicapai di masa depan. Jadi, regulasi diri pengguna media sosial adalah siswa yang mampu mengatur diri dalam menggunakan media sosial sehari-hari pada saat belajar baik di sekolah maupun di rumah dengan cara mengawasi atau mengontrol perilakunya sendiri untuk mencapai tujuan yang ingin dicapai.

Adapun hasil uji hipotesis pada penelitian ini menyatakan bahwa regulasi diri pengguna media sosial dengan motivasi belajar memiliki hubungan positif, senada dengan penelitian yang dilakukan oleh Mustofa (2014) yang menyatakan bahwa terdapat hubungan positif antara konsep diri dengan motivasi belajar siswa. Semakin tinggi konsep diri maka semakin tinggi pula motivasi belajar siswa. Penelitian yang dilakukan oleh Anggraini (2019) menyatakan bahwa terdapat hubungan negatif antara keduanya, semakin tinggi regulasi diri maka semakin rendah intensitas penggunaan media sosial. Penelitian yang dilakukan oleh Rismana, Normelani, dan Adyatma (2016) menunjukkan bahwa secara keseluruhan terdapat pengaruh yang signifikan antara penggunaan jejaring sosial terhadap motivasi belajar siswa-siswi di Kecamatan Banjarmasin Barat Tahun Pelajaran 2015/2016.

Hasil data yang diperoleh melalui analisis korelasi menunjukkan nilai signifikansi sebesar $0,000<0,05$ dan nilai koefisien 0.608 yang menunjukkan bahwa terdapat hubungan positif. Koefisien korelasi yang positif menunjukkan bahwa hubungan bersifat positif atau satu arah, sehingga hipotesis dalam penelitian ini diterima yakni terdapat hubungan yang signifikan antara regulasi diri pengguna media sosial dengan motivasi belajar siswa SMAN 1 Kendari. Hal tersebut memiliki arti bahwa semakin tinggi regulasi diri pengguna media sosial maka semakin tinggi pula motivasi belajar siswa SMAN 1 Kendari. Siswa yang memiliki regulasi diri yang baik dalam menggunakan media sosial maka akan memberikan dampak yang baik pula pada motivasi belajarnya.

\section{Kesimpulan}

Berdasarkan penelitian yang telah dilakukan, dapat disimpulkan bahwa terdapat hubungan yang signifikan antara regulasi diri pengguna media sosial dengan motivasi belajar siswa SMAN 1 Kendari. Lebih lanjut peneliti menemukan hubungan positif antara regulasi diri pengguna media sosial dan motivasi belajar, semakin tinggi regulasi diri pengguna media sosial, maka semakin tinggi pula motivasi belajar siswa. Berdasarkan hasil penelitian yang diperoleh, maka peneliti memberikan 
saran bagi peneliti selanjutnya, diharapkan untuk melihat seberapa besar peran atau pengaruh regulasi diri pengguna media sosial terhadap motivasi belajar siswa.

\section{Daftar Pustaka}

Anggraini, S. (2019). Hubungan Regulasi Diri Dengan Intensitas Penggunaan Media Sosial Peserta Didik Kelas X Di MA Al-Hikmah Bandar Lampung Tahun Ajaran 2018/2019 . (Skripsi tidak diterbitkan). Fakultas Tarbiyah dan Keguruan, Lampung.

Aprinta, G.E.B., dan Dwi, E.S.W. (2017). Hubungan Penggunaan Media Sosial Dengan Tingkat Kepekaan Sosial Pada Usia Remaja. The essenger, 1(9).

Ayun, P.Q. (2015). Fenomena remaja menggunakan media sosial dalam membentuk identitas. Jurnal Program Studi Ilmu Komunikasi, 3(2).

Bandura, A. (1989). Social Cognitive Theory. Six Theories Of Child Development. Greenwich, CT: JAI Press, 13(6).

Boeree, C.G. (2013). Personality Theories. Jogjakarta: Prismasophie.

Febritama, S., \& Sanjaya, E. L. (2018). Hubungan antara regulasi diri dengan perilaku prokrastinasi akademik pada mahasiswa. Jurnal Ecopsy, 5(2).

Friskilia, O.S., dan Winata. (2018). Regulasi Diri (pengaturan diri) Sebagai Determinan Hasil Belajar Siswa Sekolah Menengah Kejuruan Pendidikan Manajemen Perkantoran. Jurnal pendidikan manajemen perkantoran, 3(1).
Hamdu, G. \& Agustina, L. (2011). Pengaruh motivasi belajar siswa terhadap prestasi belajar IPA di Sekolah Dasar. Jurnal Penelitian Pendidikan, 1(12).

Hepilita, Y. \& Gantas, A. A. (2018). Hubungan durasi penggunaan media sosial dengan gangguan pola tidur pada anak usia 12-14 tahun di SMP Negeri 1 Langke Rembong. Jurnal Wawasan Kesehatan, 2(3).

Jarmi, A. (2017). Hubungan Penggunaan Gadget Dengan Kualitas Tidur Pada Remaja Di SMP Negeri 1 Banda Aceh. Jurnal Nursing studies, 6(1).

Manab, A. (2016). Memahami regulasi diri: sebuah tinjauan konseptual. Jurnal Psychology and Humanity, 1(1).

Maryani. (2016). Pengaruh motivasi belajar, disiplin belajar dan lingkungan belajar terhadap prestasi belajar akuntansi (survey pada siswa kelas XI IPS SMA Negeri 3 Palu). Jurnal Katalogis, 4(4).

Mustofa, A. (2014). Hubungan Konsep Diri Dengan Motivasi Belajar Siswa Kelas XII IPS MAN 1 Kota Blitar (Skripsi tidak diterbitkan). Universitas Islam Negeri (UIN), Malang.

Nurillah, A. H., \& Chusairi, A. (2018). Pengaruh regulasi diri terhadap motivasi berprestasi pada mahasiswa penerima bantuan bidikmisi di Universitas Airlangga. Jurnal Psikologi dan Kesehatan Mental, 3(2). 
Putri, W.S.R., Nurwati, N., \& Santoso, M. (2016). Pengaruh Media Sosial Terhadap Perilaku Remaja. Prosiding ks: riset \& $P K M, 1(3)$.
Zimmerman, B.J. (1990). Self-Regulated Learning and Academic Achievement: An Overview. Education Psychologist, 25 (1).

Khoiriyyah, F., Thohari, M. I., \& Jazari, I. (2019). Pengaruh media sosial terhadap prestasi belajar siswa pada mata pelajaran fiqih di Madrasah Tsanawiyah Negeri 2 Kota Malang. Jurnal Pendidikan Islam, 3(4).

Rismana, A., Normelini, E., \& Adyatma, S. (2016). Pengaruh jejaring sosial terhadap motivasi belajar siswasiswi Sekolah Menengah Pertama (SMP) di Kecamatan Banjarmasin Barat. Jurnal Pendidikan Geografi, 3(6).

Santrock, J.W. (2007). Remaja. Jilid 2. Jakarta: Erlangga.

Sifa, I.A.M., dan Sawitri, D.R. (2018). Hubungan Regulasi Diri Dengan Adiksi Media Sosial Pada Siswa SMK Jayawisata Semarang. Jurnal Empati, 2(7).

Uno, H.B. (2017). Teori Motivasi Dan Pengukurannya: Analisis Di Bidang Pendidikan. Jakarta: Bumi Aksana.

Wang, Q., Chen, Wei, dan Liang, Y. (2011). The Effects Of Social Media On College Students, MBA Students Scholarship. Jhonson \& Wales University, 13(4). 